\title{
Nursing practices centered on individuals with tuberculosis: an interface with democracy
}

\author{
Práticas de enfermagem centradas no indivíduo com tuberculose: interface com a democracia \\ Prácticas de Enfermería dirigidas al individuo con tuberculosis: interfaz con la democracia
}

$\begin{array}{r}\hline \text { Amélia Nunes Sicsú', "I } \\ \text { ORCID: 0000-0001-5217-3710 } \\ \text { Roxana Isabel Cardozo Gonzales"' } \\ \text { ORCID: 0000-0001-7180-897X } \\ \text { Fernando Mitano"v } \\ \text { ORCID: 0000-0003-4069-9314 } \\ \text { Luciana de Oliveira Sousa" } \\ \text { ORCID: 0000-0002-0366-2494 } \\ \text { Laís Mara Caetano da Silva" } \\ \text { ORCID: 0000-0001-7596-2333 } \\ \text { Individuals with tuberculosis: an interface with democracy } \\ \text { Rev Bras Enferm. 2019;72(5):1219-25. } \\ \text { doi: http://dx.doi.org/10.1590/0034-7167-2017-0380 } \\ \text { Corresponding Author: } \\ \text { Amélia Nunes Sicsú } \\ \text { ORCID: 0000-0001-6585-2560 } \\ \text { Rarianne Carvalho Peruhype" asicsu@uea.edu.br } \\ \text { ORCID: 0000-0003-3065-2555 } \\ \text { Pedro Fredemir Palha" } \\ \text { ORCID: 0000-0002-5220-4529 } \\ \hline \text { Hniversidade de São Paulo. Ribeirão Preto, São Paulo, Brazil. } \\ \text { "Universidade Federal de Pelotas. } \\ \text { Pelotas, Rio Grande do Sul, Brazil. } \\ \text { "Universidade Lúrio. Nampula, Moçambique, África. } \\ \hline\end{array}$

Submission: 06-02-2017

Approval: 05-01-2018

\begin{abstract}
Objective: To analyze whether user-centered nursing practices in TB DOT are being carried out and are contributing to democracy. Method: A cross-sectional, exploratory, descriptive study with 123 nurses in three capital cities with high incidence of TB (ManausAM, João Pessoa-PB, Porto Alegre-RS) in Brazil. Data were collected from January to June 2014. Descriptive and multiple correspondence analyzes were used. Results: It was identified that the most user-centered care actions had scores below $50 \%$, considered unfavorable to the exercise of democracy. In the analysis of the general user-centered practice score per municipality, Manaus and João Pessoa presented unfavorable results, and the municipality of Porto Alegre was partially favorable. Conclusion: The three municipalities need to advance in the implementation of user-centered practices in DOT, because their health system still has difficulties and challenges to overcome.

Descriptors: Tuberculosis; Patient-Centered Care; Democracy; Holistic Nursing; Nursing.
\end{abstract}

\section{RESUMO}

Objetivo: Analisar se as práticas de enfermagem centradas no usuário em Tratamento Diretamente Observado da tuberculose estão sendo desenvolvidas e se estão contribuindo para a democracia. Método: Estudo descritivo e exploratório, de corte transversal, realizado com 123 enfermeiros em três capitais brasileiras com alta incidência de tuberculose. Os dados foram coletados no período de janeiro a junho de 2014 e analisados mediante análises descritiva e de correspondência múltipla. Resultados: A maioria das ações de cuidado centrado no usuário apresentou escores abaixo de $50 \%$, considerados desfavoráveis ao exercício da democracia. Na análise do escore geral das práticas centradas no usuário por município, Manaus e João Pessoa apresentaram resultados desfavoráveis, e Porto Alegre, parcialmente favoráveis. Conclusão: As três capitais precisam avançar na realização de práticas centradas no usuário submetido a este tipo de tratamento, pois ainda apresentam dificuldades e desafios a serem superados pelo sistema de saúde.

Descritores: Tuberculose; Assistência Centrada no Paciente; Democracia; Enfermagem Holística; Enfermagem.

\section{RESUMEN}

Objetivo: Analizar si las prácticas de enfermería dirigidas al paciente de TDO de la TB están realizándose y si contribuyen a la democracia. Método: Estudio descriptivo exploratorio, corte transversal, realizado con 123 enfermeros en tres capitales de alta incidencia de TB (Manaus-AM; João Pessoa-PB; Porto Alegre-RS) en Brasil. Datos recolectados de enero a junio de 2014. Se utilizaron análisis descriptivo y de correspondencia múltiple. Resultados: Se identificó que la mayoría de las acciones de cuidado dirigido al paciente presentaron puntajes inferiores al 50\%, considerados desfavorables al ejercicio de la democracia. Analizando los puntajes generales de las prácticas dirigidas al paciente por municipio, Manaus y João Pessoa expresaron resultados desfavorables, y Porto Alegre, parcialmente favorables. Conclusión: Los tres municipios precisan avanzar en la realización de prácticas dirigidas al paciente de TDO, dado que aún representan dificultades y desafíos a superarse por parte del sistema de salud.

Descriptores: Tuberculosis; Atención Dirigida al Paciente; Democracia; Enfermería Holística; Enfermería. 


\section{INTRODUCTION}

Patient- or user-centered care is one of the stems of the End TB strategy, the current policy of the World Health Organization (WHO) for controlling TB, a disease that remains one of the leading causes of morbidity and mortality in the world, accounting for about 1.4 million deaths annually, and with 10.4 million new cases. It should be noted that within this structure, the directly observed therapy (DOT) is described as a care technology that contributes to the compliance to TB treatment ${ }^{(1)}$.

A healthcare system that focuses on users allows them to have the guidance and support they need to make decisions and manage their own care ${ }^{(2-3)}$. It should be emphasized that the development of innovative strategies for user-centered care has been encouraged by the $\mathrm{WHO}^{(1)}$, because the integration and valorization of ill individuals in their care plan have been associated with a better compliance to treatment and better outcomes and quality of life of ill individuals ${ }^{(4)}$.

User-centered care does not mean centralizing all responsibilities on the users, but rather recognizing that the public health system and policies should respect, protect and fulfill the users' right to health throughout the care process ${ }^{(3)}$, and in particular to guarantee their autonomy regarding the decisions related to health actions. This issue brings up democracy in its constructive aspect in which citizen participation in different social spheres cannot be seen as a limited right, and should be understood as the capacity of each individual to construct their own reality, dialoguing with all fundamental rights dimensions ${ }^{(5)}$. Democracy is considered strongly related to health promotion to citizens through health practices, promoting equality, social cohesion and well-being, reflecting on social, economic, biological and affective aspects ${ }^{(6)}$.

Although the WHO recognizes the importance of user-centered care for the creation of democratic spaces that favor TB therapy compliance, these practices are still incipient in several countries affected by the disease, such as Brazil.

It is important to emphasize that DOT splits opinions, and is seen by some as an authoritarian and alienating practice that reduces the responsibility of people with TB in relation to selfcare, infantilizing and embarrassing them ${ }^{(7-8)}$. Based on this point of view, DOT could be considered a practice that goes against the concepts of democracy.

However, it is argued that DOT is an important patient-focused strategy that remains over time as an important care technology that promotes compliance, especially in the most vulnerable individuals ${ }^{(1,8)}$, playing an important role in TB control, provided that it is improved to promote the users' autonomy, encourages their participation in discussions about their treatment and in their care plan, as well as uses community strategies and resources aiming at their compliance to DOT. The perception of the difficulties of users with TB, and the adaptation of the DOT to their reality are also indispensable actions in user-centered care, and in the construction of a more democratic society.

The directly observed therapy is part of the professional practice of nurses, and this is one of the professionals most involved in TB control actions ${ }^{(9-10)}$. However, there are still no studies analyzing whether user-centered nursing practices in DOT are being performed and are contributing to democracy, which reinforces the relevance of this research.

Studying user-centered nursing practices in different capitals of Brazil can bring important contributions to scientific knowledge and the implementation and/or improvement of TB control policies.

\section{OBJECTIVE}

To analyze whether user-centered nursing practices in TB DOT are being carried out and are contributing to democracy.

\section{METHOD}

\section{Ethical aspects}

The study was analyzed and approved by the Research Ethics Committee of the Ribeirão Preto College of Nursing and the Hospital Group Conceição, in compliance with the ethical and legal recommendations in Resolution 466/12 of the National Health Council. Participants signed a free and informed consent form after being informed of the objectives and confidentiality of the research, and of the right to stop participating, at any time, if they so wished.

\section{Study type and setting}

This is a cross-sectional, exploratory, descriptive study conducted in three capitals with a high incidence of TB, located in different regions of Brazil: North (Manaus - AM); Northeast (João Pessoa - PB); South (Porto Alegre - RS). The cities of Manaus and Porto Alegre had the highest incidence in the country in 2015 with 98.3/100,000.00 inhabitants, and 88.8/100,000.00, respectively. The city of João Pessoa had an incidence of $45.2 / 100,000,00$ inhabitants in that same year ${ }^{(11)}$.

\section{Study participants}

The study included nurses who met the inclusion criteria: being in their professional functions in health units during the data collection period, and having a minimum of six months of work in the unit. The sample consisted of 123 nurses.

\section{Measurement instrument}

The instrument validated by Silva (2015), entitled "Evaluation of Policy Transfer - Innovation, Information and Knowledge on Tuberculosis - ATP-IINFOC-TB", consisting of 39 items, was used. This instrument has 39 items with response options according to a 5-point Likert scale, namely: disagree (1), partially disagree (2), indifferent (3), partially agree (4), agree (5) $)^{(12)}$. For items with negative statements, inversions of the scores were made, aiming at the standardization of responses, for the highest score being given to the responses considered favorable. Nine variables were selected for this study; they were related to the user-centered nursing practices in the TB DOT, and were considered democratic (participation of the population in discussions about the DOT; participation of TB patients in the care plan; TB patient care planning; patient's autonomy to undergo DOT; health unit with 
strategies to promote patient compliance to the DOT; team use of community resources to compliance to the support DOT; perception of the TB patients' difficulties with the DOT, DOT adaptation to the scope of the unit; team discussion of clinical cases of TB patients on the DOT).

\section{Data collection, organization and analysis}

Data collection was carried out between January and June 2014 by researchers linked to the Group of EpidemiologicalOperational Studies on Tuberculosis (GEOTB). Data were coded and double-typed into an Excel for Windows spreadsheet and then analyzed using Statsoft's Statistica 12 software.

Initially, descriptive analysis was carried out to characterize the study participants. The following variables were used: municipality, professional category, gender, age and length of service, which were presented through relative and absolute frequencies.

For the other variables, the answers' mean value for each item of the instrument was calculated, and obtained by summing all the answers in each item and dividing it by the number of participants. For each mean value, the respective standard deviation was calculated.

In addition, a standard score of each item in the instrument was obtained by means of the following formula:

Score $_{\text {standardized }}=\frac{(\text { Mean-Minimum })}{(\text { Maximum-Minimum })} \times 100$,

with the minimum and maximum values being represented by 1 and 5, respectively, and the mean, a value between 1 and 5 . For analysis of the standardized score the following parameter was used: unfavorable results (below 50.00\%), partially favorable (50.00 to $75.00 \%$ ), and favorable (above $75.00 \%$ ).

Subsequently, a multiple correspondence analysis (MCA) was performed after the distribution of the answers in two categories: unfavorable response: responses 1, 2 and 3 (1) and favorable responses 4 and 5 (2), which composed the active variables of the perceptual map generated in the analysis. Each variable had a spatial position on the perceptual map, with the similar or associated variables being represented in near points, and the non-similar variables in distant points. As a passive variable, the municipality was inserted, which although not contributing to the dispersion of the points on the map, helps interpreting the data obtained ${ }^{(13)}$.

\section{RESULTS}

Among the 123 nurses participating in the study, 50 (40.65\%) were from João Pessoa-PB, 48 (39.02\%) from Manaus-AM and 25 (20.32\%) from Porto Alegre-RS. Most (91.87\%) were female, with the age ranging from 25 to 60 years (mean 41.43, standard deviation 9.20) and had 1 to 35 years of service (mean 10.66, SD 8.04).

In the general evaluation of the user-centered nursing care practices of the TB patients on DOT, it was observed that most of the actions had scores below $50 \%$, considered unfavorable to democracy. The variables "health unit with strategies to promote patient compliance to the DOT", "team discussion of clinical cases of TB patients on the DOT", and "DOT adaptation to the scope of the unit" had partially favorable results, and only the "perception of the TB patients' difficulties with the DOT" had favorable results (Table 1). In the evaluation per municipality, the cities of Manaus and João Pessoa had unfavorable results, and the city of Porto Alegre had partially favorable results.

When evaluating user-centered nursing care practices of TB patients per capital cities, the perceptual map (Figure 1) shows that the unfavorable responses regarding the participation of the population in discussions about the DOT, and the use, by the team, of community resources to support compliance to the DOT, and the favorable responses regarding the perception of the TB patients' difficulties with the DOT, and DOT adaptation to the scope of the unit were close to the center of the perceptual map corresponding to the majority of responses of the participants of the three capitals.

Table 1- User-centered nursing practices related to directly observed therapy for tuberculosis*, Manaus-Amazonas, João Pessoa-Paraíba, Porto AlegreRio Grande do Sul, Brazil, 2014

\begin{tabular}{|c|c|c|c|}
\hline Variables & Average & Stand. Score & SD \\
\hline V1 - Participation of the population in discussions about the DOT & 1.95 & 23.77 & 1.95 \\
\hline V2 - Participation of TB patients in the care plan & 2.46 & 36.59 & 1.60 \\
\hline V3 - TB patient care planning & 2.88 & 46.93 & 1.65 \\
\hline V4 - Patient's autonomy to undergo DOT & 2.97 & 49.39 & 1.64 \\
\hline V5 - Health unit with strategies to promote patient compliance to the DOT & 3.31 & 57.79 & 1.63 \\
\hline V6 - Team use of community resources to support compliance to the DOT & 2.20 & 30.12 & 1.50 \\
\hline V7 - Perception of the TB patients' difficulties with the DOT & 4.19 & 79.67 & 1.28 \\
\hline V8 - DOT adaptation to the scope of the unit & 4.00 & 75.00 & 1.39 \\
\hline V9-Team discussion of clinical cases of TB patients on the DOT & 3.60 & 65.08 & 1.49 \\
\hline Cities & Average & Stand. Score & SD \\
\hline Manaus & 2.99 & 48.83 & 1.59 \\
\hline João Pessoa & 3.02 & 49.75 & 1.30 \\
\hline Porto Alegre & 3.29 & 57.93 & 1.40 \\
\hline
\end{tabular}

Note: DOT - directly observed therapy for tuberculosis; TB - Tuberculosis; ${ }^{*}$ Representation of averages and standardized scores. 
The municipality of Porto Alegre showed greater proximity to the favorable responses regarding the participation of TB patients in the care plan; care planning for TB patients, and patients' autonomy to undergo the DOT. On the other hand, the city of João Pessoa presented proximity with the unfavorable answers regarding the same variables.

The city of Manaus showed greater proximity to the unfavorable responses regarding the health unit having strategies to promote patient compliance to the DOT, and the team discussion of clinical cases of TB patients on the DOT, and the favorable response regarding the patients' autonomy to undergo the DOT.

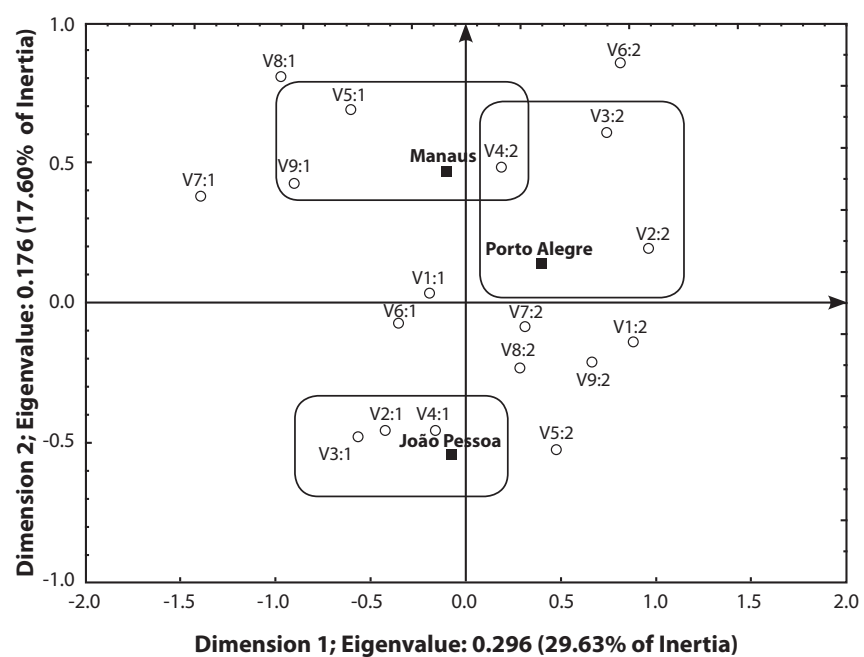

Note: V1 - Participation of the population in discussions on the DOT; V2 - Participation of TB patients in the care plan; V3 - TB patient care planning; V4 - Patient's autonomy to undergo DOT, V5 - Health unit with strategies to promote patient compliance to the DOT; V6-Team use of community resources to support compliance to the DOT; V7-Perception of the TB patients' difficulties with the DOT; V8-DOT adaptation to the scope of the unit; V9-Team discussion of clinical cases of TB patients on the DOT. Answer Options: 1. Unfavorable response; 2. Favorable response. Source: Research data, 2015.

Figure 1 - Perceptual map of user-centered nursing care practices regarding TB DOT*. Manaus-Amazonas, João Pessoa-Paraíba, Porto Alegre-Rio Grande do Sul, Brazil, 2014

\section{DISCUSSION}

User-centered care is an important activity in the control of TB, and represents a challenge for the construction of a more inclusive, autonomous and fair society. The results of this study showed that important actions for democracy, such as the participation of the population in discussions about DOT; participation of TB patients in their individual care plan; TB patient planning care; patients' autonomy to undergo the DOT; the health unit using community resources to promote patient compliance to the DOT are not being performed by most nurses.

The lack of popular participation, non-inclusion of TB patients in their care plan, lack of encouragement of TB patients' autonomy, and non-use of community resources go against democratic precepts, because users start having a secondary role in the centrality of treatment, so there is less possibility of them exercising their autonomy to make decisions that seem most appropriate to them ${ }^{(5)}$.

In the comparative analysis of the municipalities, the city of Porto Alegre had the best results in the general score, which allows to infer that the municipality has been developing actions that better characterize user-centered care, favoring more democratic practices in the control of TB.

The three capitals showed unfavorable results in terms of population participation in discussions on the DOT and the use of community resources to support compliance to the DOT. A similar result was identified in a study carried out in the city of João Pessoa (state of Paraíba), which revealed the lack of partnerships with the community aiming at the empowerment of TB patients ${ }^{(14)}$. For the authors, this reality may mean an important point to be worked on for the improvement of disease control actions.

The democratization of health actions permeates the participation and involvement of the population in the control of diseases, generating necessary changes for the construction of social wellbeing based on a conscious and mobilized collective ${ }^{(15)}$. This way, in the current scenario of coping with TB in Brazil, it is essential to consider the participation of the population and the community in TB control actions. The development of DOT requires the participation of the population and the use of community resources, since this mode of monitoring TB treatment often requires the collaboration and partnership of family, friends and community. When considering community resources such as groups for support and self-help, church, family, friends, residents' association, etc., health teams denote user-centered care mobilizing resources that contribute to differentiated care for TB patients.

This is a fact that is confirmed in the literature: the relationship between TB and poverty, which is referenced as a social disease that develops in a context of social disadvantage ${ }^{(16-17)}$. Thus, this is a population with greater social vulnerability, which requires joint efforts, not just the health sector, to support users. Communitybased initiatives can create valuable support for overburdened public health services because they can help reach out to groups that are routinely excluded (criminalized and stigmatized groups), and who need support to have access and adhere to health care actions, directing care to the needs of users and adapting actions to the social context, as well as bringing to light emerging needs and priorities, strengthening systems that respond to the needs of the people and not the needs of a sector ${ }^{(18)}$.

The favorable results regarding the perception of TB patients on the difficulties with the DOT, and DOT adaptation to the scope of the unit in the three capitals studied, signal the awareness of the nursing team about the need to innovate their practice, with actions favoring the practice of DOT, and are based on usercentered care. The literature has highlighted that the actors' ability to innovate in the adaptation of their practice to the context is essential for the success of any disease control policy ${ }^{(19)}$.

It should be noted that individuals with TB present several difficulties during their illness process, including: isolation, rejection of the family and community, loss of employment, reduction of opportunities, and stigma associated with the disease ${ }^{(20)}$. However, even if it is weakened by its existential conditions, individuals with TB have indispensable knowledge to promote care that goes beyond technical and normative aspects, and it is important that their demands are valid to direct health interventions ${ }^{(21)}$. Hence, these individuals need to be considered as part of a living health network, with its own identity, and that carries within it innumerable possibilities of shared experiences and 
meanings that should be considered by health policies. It should be emphasized that it is not possible to have both an excluding society and a democratic policy. Therefore, it is indispensable that the singularities and difficulties of the user do not remain unrelated to the treatment process and nursing care.

Flexible nursing practices, adaptive to the area of influence, are necessary for the promotion of ill people's health and well-being, because health care is not isolated from the social space in which individuals are inserted, and each space has its own characteristics, important aspects for the success of policies aimed at controlling diseases. Moreover, the literature points out that there is no possibility of disassociating fundamental social rights from the concept of constructive democracy, since they are minimal elements for the individuals to be able to influence their reality ${ }^{(5)}$, either when based on health, illness or in the coexistence of both.

A differentiation in the practice of nursing was also observed. While one municipality prioritizes or does not prioritize a certain activity, others prioritize or do not prioritize others, which may vary according to the context of each scenario studied. While in the practice of the nurses of the city of Porto Alegre there is appreciation of the participation of TB patients in the care plan, of the care planning itself, and of the ill person's autonomy to undergo the DOT, in the municipality of João Pessoa these practices are still poorly carried out by the nurses.

The unfavorable results in João Pessoa may be pointing to difficulties in the practice of the DOT in this municipality, because care planning, inclusion of the ill person in the planning of their treatment process, and the encouragement of their autonomy are important actions for valuing the subject, which promote greater encouragement for the acceptance and development of the guidelines of health professionals related to the treatment of the disease. Also, not promoting the inclusion and autonomy of TB patients in their treatment process goes against the first pillar of the End TB strategy, patient-centered care and the precepts of a constructive democracy.

Care planning for the individual with TB is an essential activity of nurses and should be carried out based on the needs of ill users; thus, the patients' participation in their care planning, which is fundamental for the strengthening of their autonomy and for treatment compliance is important. For this to happen, it is important to establish a bond and trust relationship between ill users and professionals ${ }^{(22)}$, so as to promote the humanization of care through communication, shared decision-making, and support for self-management ${ }^{(3)}$. DOT is important for the establishment of relations of embracement, bonding and accountability, allowing the relationship between professionals and TB patients, and the extension of the therapeutic focus beyond the medical treatment ${ }^{(23-24)}$.

This way, DOT is a user-centered practice, and must involve each ill person individually with education/counseling, understanding their motivations and improving behavioral skills within the context of social, structural and local cultural factors ${ }^{(3)}$, considering it as an active actor in the treatment process itself ${ }^{(25)}$.

The unfavorable outcome regarding the fact that the health unit has strategies to promote patient compliance to the DOT in the municipality of Manaus may interfere in the control of $T B$, because compliance is fundamental to the successful treatment and cure of $\mathrm{TB}^{(1)}$. This aspect has remained an important cross-sectional element in the control of TB over the years ${ }^{(26-27)}$. In this context, health teams, together with the community and other sectors, should promote compliance strategies, because the lack of, or low compliance to treatment results in increased suffering, mortality and multidrug resistance ${ }^{(28)}$, not favoring a broad social protection system, including health, a sine qua non condition for the existence of human dignity, access to public health policies and the rule of law, founding aspects of democracy ${ }^{(29)}$.

The municipality of Manaus also had unfavorable results regarding the discussion of clinical cases of TB patients on the DOT. This action is important to diagnose the difficulties inherent to ill users, which can create barriers to treatment success. However, it should be stressed that this discussion should transcend biological aspects. The literature indicates that nurses are the main people responsible for TB control actions ${ }^{(9-10,30)}$. Sharing of information and knowledge in their work routine is important to promote comprehensive, continuous and organized care of the related population ${ }^{(31)}$. Such actions are also important in user-centered care and the exercise of democracy.

It should be emphasized that all health practices should be automatically user-centered and democratic, because the Brazilian health system is governed by the principles of universality, equity and comprehensiveness ${ }^{(32)}$.

\section{Study limitations}

Because it is a cross-sectional study, the fact that the interviews are performed in a single moment in time can be a limitation, making it difficult to consider whether the practices performed are causal or not with a greater degree of certainty.

\section{Contributions to the area of nursing, health or public policy}

This study presents results about important actions that can guide nurses' performance to qualify and/or reconfigure the nursing practice, so as to focus their actions on users, to construct more democratic spaces in health care that favor the quality of care delivery and the well-being of ill people, and thus a greater contribution to the disease control.

\section{CONCLUSION}

The results of this study allow us to conclude that user-centered nursing practices on the DOT are still incipient and little democratic in the Brazilian settings studied, especially in the municipalities of Manaus and João Pessoa, and need to move forward in order to insert patients and the community in the care planning, as well as to stimulate their autonomy for co-responsibility in the treatment process. It is the moment for a paradigm shift in the way DOT is thought and planned, with a view to the insertion of individual- and community-centered care aimed at promoting human dignity and access to the rule of law, to achieve the desired impact and move towards controlling and eliminating the disease. The results of this research instigate to think whether the non-accomplishment of democratic actions centered on the user would be the main reason why DOT does not have the same positive effect in all populations. This questioning serves as an anchor for future research. 
It is important to point out that the insertion of such actions contribute to TB control, to the person's well-being in their biological and psychosocial aspect, and, consequently, to the democratic rule of law.

\section{FUNDING}

This research was funded by the National Council for Scientific and Technological Development (CNPq, case 479180/2011-3).

\section{REFERENCES}

1. World Health Organization-WHO. Implementing The End TB Strategy: The Essentials. Geneva: WHO, 2015.

2. Silva D. Helping measure person-centred care [Internet]. Londres: Health Foundation; 2014[cited 2017 May 9]. Available from: http://www. health.org.uk/sites/default/files/HelpingMeasurePersonCentredCare.pdf

3. Donnell MRO, Daftary A, Frick M, Hirsch-Moverman Y, Amico KR, Senthilingam M, et al. Re-inventing adherence: toward a patient-centered model of care for drug-resistant tuberculosis and HIV. Int J Tuberc Lung Dis [Internet]. 2016[cited 2017 May 9];20(4):430-434. Available from: https://www.ncbi.nlm.nih.gov/pmc/articles/PMC4863995/

4. Kuntz J, SAfford MM, Singh JÁ, Phansalkar S, Slight SP, Her QL, et al. . Patient Education and Counseling [Internet]. 2014 [cited 2017 Out 10];97(3):310-26. Available from: http://www.sciencedirect.com/science/article/pii/S0738399114003711?via\%3Dihub

5. Coutinho CMC, Morais JLB. Objetivos do Milênio e democracia construtiva: Os Direitos Fundamentais como elementos constitutivos do estado democrático de direito. Rev Opin Jur [Internet]. 2016 [cited 2017 Apr 11];14(18):119-43. Available from: http://periodicos.unichristus. edu.br/index.php/opiniaojuridica/article/view/230.

6. Vidal ECF, Saraiva KRO, Dodt RCM, Vieira NFC, Barroso MGT. Democracia e participação cidadã: um debate sobre as práticas de educação em saúde. Rev Gaúcha Enferm [Internet]. 2008 [cited 2017 Apr 5];29(3):475-80. Available from: http://seer.ufrgs.br/ RevistaGauchadeEnfermagem/article/view/6777.

7. Arnadottir T. Tuberculosis and Public Health: Policy and Principles in Tuberculosis Control. [Internet] Paris, França: International Union Against Tuberculosis and Lung Disease, 2009 [cited 2017 Oct 12]. Available from: https://www.theunion.org/what-we-do/publications/ technical/english/pub_tbpublic-health_eng.pdf

8. Queiroz EM, De-La-Torre-Ugarte-Guanilo MC, Ferreira KR, Bertolozzi MR. Tuberculose: limites e potencialidades do tratamento supervisionado. Rev Latino-Am Enfermagem. 2012 ;20(2):369-377. doi: http://dx.doi.org/10.1590/S0104-11692012000200021

9. Caliari JS, Figueiredo RM. Tuberculose: perfil de doentes, fluxo de atendimento e opinião de enfermeiros. Acta Paul Enferm. 2012;25(1):43-7. doi: http://dx.doi.org/10.1590/S0103-21002012000100008

10. Souza KMJ, Sá LD, Silva LMC, Palha PF. Nursing performance in the policy transfer of directly observed treatment of tuberculosis. Rev Esc Enferm USP [Internet]. 2014 [cited 2017 March 18];48(5):874-82. Available from: http://www.revistas.usp.br/reeusp/article/view/103085

11. Ministério da Saúde (BR). Fundação de Vigilância em Saúde. Perspectivas brasileiras para o fim da tuberculose como problema de saúde pública BolEpidemiol[Internet]. 2016 [cited 2017 Apr 9];47(13). Available from: http://portalms.saude.gov.br/images/pdf/2016/ marco/24/2016-009-Tuberculose-001.pdf

12. Silva $L M C$, Surniche $C A$, Sicsú $A N$, Mitano F, Nogueira JA, Santos $C B$, et al. Elaboração e validação semântica de um instrumento de avaliação da transferência do tratamento diretamente observado como política de controle da tuberculose. Rev Panam Salud Publica [Internet]. 2015 [cited 2017 May 14];38(2):129-35. Available from: https://www.scielosp.org/pdf/rpsp/2015.v38n2/129-135/pt

13. Nascimento A, Almeida RMVR, Castilho SR, Infantosi AFC. Análise de correspondência múltipla na avaliação de serviços de farmácia hospitalar no Brasil. Cad Saúde Pública . 2013;29(6):1161-72. doi: http://dx.doi.org/10.1590/S0102-311X2013000600013

14. Sá LD, Gomes ALC, Carmo JB, Souza KMJ, Palha PF, Alves, RS, Andrade SLA. Educação em saúde no controle da tuberculose: perspectiva de profissionais da estratégia saúde da família. Rev Eletr Enferm [Internet] 2013 [cited 2017 Apr 9];15(1):103-11. Available from: https://www. fen.ufg.br/fen_revista/v15/n1/pdf/v15n1a12.pdf

15. Lopes FN, Lana FCF. Participação popular no controle da hanseníase: um desafio para o serviço de saúde. Rev Enferm UERJ [Internet]. 2015 [cited 2017 Apr 9];23(2):235-40. Available from: http://www.facenf.uerj.br/v23n2/v23n2a15.pdf

16. Rodrigues ILA, Motta MCS, Ferreira MA. Social representations of nurses about tuberuclosis patients. Acta Paul Enferm [Internet]. 2013 [cited 2016 Oct 30];26(2):172-8. Available from: http://www.scielo.br/pdf/ape/v26n2/en_v26n2a11.pdf

17. Saunders MJ, Carlton AE. Fighting poverty to prevent tuberculosis. Lancet Infect Dis[Internet]. 2016 [cited 2016 Nov 05];16(4):395-6. Available from: http://www.thelancet.com/journals/laninf/article/ PIIS1473-3099(15)00434-X/fulltext

18. Collins CJ, Greenall MN, Mallouris C, Smith SL. Time for full inclusion of community actions in the response to AIDS. J Int AIDS Soc. [Internet]. 2016 [cited 2017 Oct 10];19(1):20712. Available from: https://www.ncbi.nlm.nih.gov/pmc/articles/PMC4833769/pdf/JIAS-19-20712.pdf

19. Bissel K, Lee K, Freeman R. Analysing policy transfer: perspectives for operational research. Int J TubercLung Dis [Internet]. 2011 [cited 2017 Oct 10];15(9):1140-8. Available from: http://www.ingentaconnect.com/content/iuatld/ijtld/2011/00000015/00000009/art00003

20. Tadesse S. Stigma against Tuberculosis Patients in Addis Ababa, Ethiopia. Plos one [Internet] 2015 [cited 2016 Oct 24];11(4). Available from: http://journals.plos.org/plosone/article?id=10.1371/journal.pone.0152900 
21. Aneas TV, Ayres JRCM. Significados e sentidos das práticas de saúde: a ontologia fundamental e a reconstrução do cuidado em saúde. Interface (Botucatu). 2011;15(38):651-62. doi: http://dx.doi.org/10.1590/S1414-32832011000300003

22. Brunello MEF, Cerqueira DF, Pinto IC, Arcênio RA, Gonzales RIC, Villa TCS, et al . Vínculo doente-profissional de saúde na atenção a pacientes com tuberculose. Acta Paul Enferm. 2009;22(2):176-82. doi: http://dx.doi.org/10.1590/S0103-21002009000200010

23. Frieden TR, Sbarbaro JA. Promoting adherence to treatment for tuberculosis: the importance of direct observation. BullWorld Health Org [Internet]. 2007[cited 2016 Oct 24];85(5). Availabe from: https://www.ncbi.nlm.nih.gov/pubmed/17894191

24. Santos TMMG, Nogueira LT, Arcêncio RA. Atuação de profissionais da Estratégia Saúde da Família no controle da tuberculose. Acta Paul Enferm. 2012;25(6):954-61. doi: http://dx.doi.org/10.1590/S0103-21002012000600020

25. Gaudenzi POF. O estatuto da medicalização e as interpretações de Ivan Illich e Michel Foucault como ferramentas conceituais para o estudo da desmedicalização. Interface. 2012; 16(40): 21-34. doi: http://dx.doi.org/10.1590/S1414-32832012005000020

26. Souza MSPL, Pereira SM, Marinho JM, Barreto ML. Características dos serviços de saúde associadas à adesão ao tratamento da tuberculose. Rev Saúde Pública. 2009;43(6):997-1005. doi: http://dx.doi.org/10.1590/S0034-89102009005000085

27. Vieira AA, Ribeiro SA. Adesão ao tratamento da tuberculose após a instituição da estratégia de tratamento supervisionado no município de Carapicuíba, grande São Paulo. J Bras Pneumol. 2011;37(2):223-31. doi: http://dx.doi.org/10.1590/S1806-37132011000200013

28. DiStefano MJ, Schmidt H. mHealth for Tuberculosis Treatment Adherence: a framework to guide ethical planning, implementation, and evaluation. Glob Health: Sci Pract[Internet]. 2016[cited 2017 Apr 9];4(2):211-21. Available from: https://www.ncbi.nlm.nih.gov/pmc/articles/ PMC4982246/

29. Maders AM. O direito à saúde no Estado Democrático de Direito Brasileiro. Rev Direito, Santa Cruz do Sul [Internet]. 2010 [cited 2017 Apr 9];33:19-37. Available from: https://online.unisc.br/seer/index.php/direito/article/view/1691

30. Oblitas FYM, Loncharich N, Salazar ME, David HML, Silva I, Velásquez D. O papel da enfermagem no controle da tuberculose: uma discussão sob a perspectiva da equidade. Rev Latino-Am Enfermagem [Internet]. 2010. [cited 2017 Apr 09];18(1):09 telas. Available from: http://www. scielo.br/pdf/rlae/v18n1/pt_20.pdf

31. Figueiredo ENA. Estratégia de Saúde da Família na Atenção Básica do SUS [Internet]. UNA-SUS, UNIFESP, 2012[cited 2017 Apr 09]. Available from: http://www.unasus.unifesp.br/biblioteca_virtual/esf/2/unidades_conteudos/unidade05/unidade05.pdf

32. Mattos RA. Princípios do Sistema Único de Saúde (SUS) e a humanização das práticas de saúde. Interface (Botucatu) [Internet]. 2009 [cited 2017 Apr 16];13(Suppl 1):771-80. Available from: http://www.scielo.br/pdf/icse/v13s1/a28v13s1.pdf 